\title{
Robert Kolej Mezunları ve Meşhurları
}

\author{
Robert College Graduates and Famous Graduates
}

\author{
Fatma ACUN ${ }^{\star *}$
}

\begin{abstract}
Öz: 1863 yılında dört öğrenci ile İstanbul'da Bebek sırtlarında eğitime başlayan Robert Kolej, Amerika Birleşik Devletleri'nin kendi toprakları dışında, uzak diyarlarda kurduğu ilk misyoner okuludur. O sebeple, kuruluş aşamasında başarılı olması konusunda şüpheler belirmiştir. Ancak, iyi yönetimi, seçilen idareci ve hocaların maddiyat yerine maneviyatı ve misyonu ön plana koymaları ve bu misyona kendilerini adamaları sayesinde, kolej kısa sürede başarıya ulaşmış ve dünya standartlarında eğitim veren bir kurum haline dönüşmüştür. Mezun sayısı hızla artarak Osmanlı son döneminde kurulan ulus devletlerin idari, bürokratik ve teknik vb. elaman ihtiyacını karşılamıştır. Dünyaya açık olmaları dolayısıyla, dünyadaki gelişmeleri ülkelerine taşıyanlar ve ilkleri gerçekleştirenler de Kolej mezunları arasından çıkmıştır. Bu çalışmada, Kolejin kuruluşu, öğrencileri ve mezunları hakkında bilgi verildikten sonra, verilen eğitime değinilmiş, ardından da Türk mezunları ve Cumhuriyetin ilk yıllarında ülkeye yaptığı katkılar çeşitli alanlara göre sıralanmıştır. Çalışmadan elde edilen netice şudur; Kolej eğitimi, insanın eğitim yoluyla değiştirile bilineceği düşüncesine uygun olarak düzenlenmiş, öğrencileri bilgi ile donatmanın yanı sıra, ahlaki ve dini yönlerini geliştirmek üzere her türlü çaba sarf edilmiştir. Bu suretle, modern bilgiye ve sağlam manevi donanıma sahip olan öğrenciler, içinde yaşadıkları topluma katkı ve katma değer sağlayan bireyler haline gelmiştir. Kolej de bu suretle, Amerikan toprakları haricindeki en eski ve köklü okul olma sıfatını kazanmıştır.
\end{abstract} Amerikan Koleji

Abstract: Robert College started education with only four students at the hills of Bebek in İstanbul in 1863. It was the first missionary school established outside the United States, beyond the Atlantic. Many people doubted that it would be successful. However, best administration and the selection of the best teachers made the college and its graduate's best among its peers. The number of College graduates increased rapidly and they contributed in many fields to the life and well being of the society in which they lived. In this article, firstly, information will be given on the College, its registered students and its graduates followed by the information on the education given at the College. Finally, Turkish graduates of the College are studied on the basis of various fields that they contributed to the society in which they were living. The findings of the study are that the College has been

\footnotetext{
* Bu çalışma, makalenin yazarı tarafından yürütülmekte olan, "Osmanlı'dan Cumhuriyet'e Yabancı Okullar: Robert Kolej'de Okuyan Türk Öğrenciler Üzerine Prosopografik Bir Çalışma (1863-1975) (TÜBITAK 1001 Projesi, Proje No: 113K135) konulu kapsamında hazırlanmıştır. Çalışmayı mümkün kılan katkılarından dolayı TÜBITAK'a teşekkür edilmektedir.

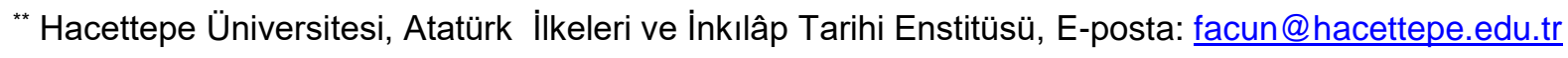


successful thanks mainly to its education that was organized around the principle that education is best instrument to change people and thus the society. Its students equipped with the best knowledge and learned the best moral and religious values that made them ready for future. These qualities distinguished them among their peers and gave them knowledge and courage to contribute to their society. Robert College, thus, become the best and the oldest educational institution established outside the United States.

Keywords: Robert Kolej, Foreign Schools, Missionary, Education, Robert College Graduate, American College

\section{Giriş}

19. yüzyıl Avrupalı ve Amerikan misyonerlerin Osmanlı topraklarında yoğun faaliyetlerde bulunduğu dönemdi. Eğitim, dini, tıbbi vb. misyonlarla, yabancılara tanınmış olan imtiyazlar kapsamında ve bu imtiyazları en geniş sınırlarına kadar zorlayarak, faaliyet alanlarını genişletip yaygınlaştırma yoluna gidiyorlardı. Öyle ki, özellikle Anadolu, bu yüzyılda adeta, misyonerlerin cirit attığı bir alan haline gelmişti. Misyonerlerin Osmanlı toplumuna en kolay nüfuz ettiği alanların başında eğitim geliyordu. Amerikan misyonerlerin faaliyetleri neticesinde, 1863 yılında İstanbul'da Robert Kolej açıldı. Açılmakla kalmayıp, Kolej eğitimini bir gereklilik haline de getirdi. Misyonerlerin gözünde "aydınlanma" kolej eğitimi ile sağlanabilirdi. Batıda böyle olmuştu, Türkiye'de de böyle olmalıydı. American Board of Comissioners for Foreign Mission, ilkokulları destekliyor ve din adamı ve öğretmen yetiştirmek için elinden geleni yapıyordu. ${ }^{1}$ Fakat diğer mesleklerden insan yetiştirmek için bir girişimde bulunmuyordu. Kolej eğitimi, insanların aydınlanması ve Hıristiyanlığın canlanması için gerekliydi. Bu ihtiyacı karşılamak üzere, New York'lu zengin tüccar ve yardımsever Christopher Rheinlander Robert İstanbul'da bir kolej kurmak üzere planlar yaptı. Daha önce, başkaları da benzeri planlar yapmıştı, fakat gerekli maddi kaynak bulunamadığından bu planlar hayata geçirilemedi. Christopher Robert, kolej için çok fazla para ve enerji harcadı. Öyle ki, dostları, bu çabaların yaşam enerjisini tükettiği ve ömrünü kısalttığını söylenmektedir (Origin and History of Robert College, s. 6)

Christopher Robert, 1856 yılında Cyrus Hamlin ile tanıştı. Hamlin 1839 yılında Osmanlı topraklarına gelmiş, yetenekli ve bilgili bir misyonerdi (Freely, 2009: 5-20 ). Kırım Savaşı (1853-1856) sırasında Christopher Robert'in bulunduğu gemi İstanbul limanına

\footnotetext{
${ }^{1}$ Kısaca American Board olarak bilinen bu misyoner teşkilatı 1810 yılında Boston'da kuruldu. Amerika'daki Protestan misyoner örgütlerinin en kdemlisi ve etkilisiydi. Protestan misyoner örgütlerin dünyayı kendi aralarında paylaştıklarında, Osmanlı Devleti'nin şansına Amerika düşmüş, böylece, Osmanlı ülkesi Amerikalı misyner örgütlerinin çalışma alanı haline gelmişti. Uygur Kocabaşoğlu, Anadolu'daki Amerika, İmge Yayınevi: Ankara, 2000, s. 16-17.
} 
yaklaşırken, yanından geçen, iyi pişirilmiş beyaz ekmek dolusu bir tekneyi fark etti ve bunu kimin pişirdiğini sordu. Cyrus Hamlin tarafından, Selimiye kışlasında yatmakta olan yaralı İngiliz askerleri için pişirildiğini öğrenince onunla tanışmak istedi. Zengin tüccar Christopher Robert ile kendini misyonerliğe adamış Hamlin'in tanışması, bir bakıma servet ile inancın, hayırseverlikle kendini adamışlığın tanışmasıydı. Her ikisinin bir araya gelmesi, Amerikan toprakları haricinde, en eski ve prestijli Amerikan kolejinin kurulmasıyla neticelendi. Christopher Robert, kolejin kurulması için gerekli olan maddi desteğin büyük bir kısmını sağlarken, Hamlin ise ilave desteğin bulunması ve kolejin kurulmasının sorumluluğunu üstlendi (The Story of Robert College at Constantinople, s. 4).

Christopher Robert, 1860 yılında, Hamlin'e American Board ile bağlantısını koparmasını ve Amerika'ya gelerek kolej için para toplamasını teklif etti. Başlangıç parası olarak da Hamlin'e 10.000 Dolar verdi. Hamlin Amerika'ya döndü. Christopher Robert bu aşamada daha fazla yatırım yapmayı ve kendi adını taşıyan bir okul kurmayı aklına bile getirmemişti. Kalan parayı, zengin hayırseverlerden temin etmesi için Hamlin'e yol gösterdi. Ancak, Hamlin bunu başaramadı. Bunun üzerine Christopher Robert 30.000 Dolar vererek, onu İstanbul'a gönderdi ve kolej inşaatını başlatmasını istedi. Bu miktar para ile kolejin tamamlanması mümkün değildi. Kalan paranın toplanması işi, bir yıl daha sürmesi beklenen savaş sonrasına bırakıldı. Fakat savaş devam etti, Christopher Robert de, 1871 yılına kadar para vermeye devam etti. Bu esnada Kolej sekiz yıllını doldurmuştu. Hamlin Amerika'ya geldi. Amacı 300.000 Dolar toplamaktı; fakat ancak 25.000 Dolar toplayabildi (The Story of Robert College at Constantinople, s. 1).

Para toplama konusunda bu derece başarısız olması, kısmen dönemin mali sıkıntılarıyla fakat, daha çok da, Robert'in büyük bir servet sahibi olmasıyla ilgiliydi. Hayırseverler, Christopher Robert'in servetini abartmışlar ve koleji kendi parasıyla kurabileceğini düşünmüşler, bu yüzden de destek vermemişlerdi. Robert, 1878 yılında ölümüne kadar koleji destekledi ve ölümünden sonraki üç yıl için de ihtiyaçlarını karşıladı. Toplamda 297.000 Dolar bağışta bulunmuştu. Kurulmasına yaptığı katkılar dolayısıyla, mütevelli heyeti tarafından, koleje adı verildi (The Story of Robert College at Constantinople, s. 2).

Kolej kuruluşundan beri, ücretlidir. Yatılı olanlar ve gündüzlü olanlar için ayrı ücretler belirlenmiştir. Talep edilen ücretler oldukça yüksektir. Bu sebeple, fakir fakat gelecek vaat eden öğrencilerden ücretin yarısı talep edilmiştir. Kolejin en başarılı öğrencileri de bu grup arasından çıkmıştır (The Story of Robert College at Constantinople, s. 11). Öğrenim ücreti 
herkesten, hatta misyoner ve bakan çocuklarından da alınmıştır. Bu manada kolej az miktardaki parayla çok işler başarmıştır. Verdiği eğitimin ve yetiştirdiği öğrencilerin kalitesi ve işleyişinin mükemmelliği dolayısıyla, Amerika ve Osmanlıdaki çeşitli kurum ve kişilerden takdir görmüş, onay almıştır. İlaveten, kolej Avrupa'da, Osmanlı'daki en önemli ve tesirli eğitim kurumu olarak tanınmıştır. Osmanlıda ve Türkiye'de, İran, Rusya ve yeni kurulan güneydoğu Avrupa ülkelerinde, eğitim konusunda güven kazanarak saygın bir yere sahip olmuştur. Kolej bir Hıristiyan misyoner okuludur. İstanbul'daki yabancı yüksek öğrenim kurumları ise tamamen ateisttir (The Story of Robert College at Constantinople, s. 4). Bu sebeple, Doğu Kiliselerinin en üst düzey yetkilileri, Robert kolejin önemini takdir etmekte ve ateizmle mücadelesini desteklemektedir. Robert Kolej’i de destekleyen American Board'ın en önemli misyonu, "dinsizler arasında Hıristiyanlığı yaymak" tı. Bu misyon layıkıyla yerine getirilmiş, dünyada dinsiz (heathen) nerdeyse kalmamıştı (Kocabaşoğlu, 2000: 16). Dünyanın en etkili merkezlerinden olan İstanbul'da olması, Doğu milletlerine yeni hayat tarzı ve yeni düşünceler aşılaması, Kolejin önemini bir kat daha artırmaktadır. Kolej, Amerikan okulu olması dolayısıyla, hem Osmanlıda, Türkiye'de hem de Avrupa'da, Amerika'yı temsil eden bir kurum olarak görülmekte, Amerika'nın Osmanlı ve Doğu'daki tesirini yaymak üzere sarf ettiği çabalar takdir edilmektedir. Kuruluşunda ve takip eden yıllarda çok emek, para ve çaba sarf edilen Kolej, Amerikalı misyonerlerin, Amerika dışında kurdukları ilk ve tek en başarılı okul olmuştur. Kolejde hizmet veren personel ve hocaların fedakarlıklarının, inanç ve ideallerinin bunda katkısı çok büyüktür (The Story of Robert College at Constantinople, s. 5).

\section{Yöntem}

Araştırmada konuya ilişkin arşiv belgeleri ve arşivden derlenen basılı belgeler kullanılmıştır. Bu belgeler ve basılı eserler Columbia University, Rare Books and Manuscripts Library (New York, USA) ve University of Illinois Kütüphanesi dijital Arşivi'nden derlenmiştir. Belgelerden derlenen bilgiler iki türdür; sayısal ve sözel. Sayısal bilgiler Tablolar halinde sunulmuş ve basit aritmetik hesaplarıyla araştırma konusu doğrultusunda işlem yapılmıştır. Sözel verilerden ise, konuyu daha iyi anlamak için istifade edilmiştir. Araştırma sorusu şudur; Robert Kolej'in geneldeki mezunları ve Türk mezunları topluma ne tür katkılarda bulunmuştur ve Kolejden ne derece istifade etmişlerdir? Bu soruyu cevaplamak üzere önce, Kolej'de verilen eğitim, ardından öğrencilerin kolej'den mezun olma durumu incelenecek ve mezunların topluma katkılarını anlamak üzere mesleklerine dair 
istatistiki bir değerlendirme yapılacaktır. Türk mezunlara ilişkin veriler sayısal olmadığından, benzeri türden istatistiki hesaplar yapmak yerine, mezunların topluma yaptığı katkılar, çeşitli alanlar halinde sunulacaktır. Türk mezunlara ve sayılarına ilişkin istatistiki veriler mevcut olmakla birlikte bu araştırmada kullanılmamıştır. Bunun sebebi, mevcut rakamların güvenilir ve kesin olmamasıdır. Bu tür bir çalışma, makalenin yazarının yürütücüsü olduğu projenin tamamlanmasıyla daha güvenilir biçimde yapılacak, elde edilecek sonuçlar da, bu suretle geçerli olacaktır.

\section{Bulgular}

\section{Kolej Eğitimi}

Kolej müfredatı, insanın karakterinin ve algılama duyularının eğitim yoluyla geliştirile bilineceği/değiştirilebilineceği düşüncesine dayanan hümanist teoriye göre biçimlendirilmiştir. Dolayısıyla, öğrencilerin ahlaki ve dini karakterlerini geliştirmek üzere her türlü çaba sarf edilmiştir. Dini eğitim ayrılıkçı ve tartışmalı değildir. Kutsal metinlere ve herkes için özgürlük prensibine dayandırıımıştır. Bütün öğrencilerin, disiplinli biçimde, sabah duasına, öğleden sonra İncil okumasına ve gece de dini sohbete katılması gerekmektedir (The Story of Robert College at Constantinople, s. 49). Aşağıda, TABLO 1'de, kuruluş yıllarında Kolejde okutulan dersler sınıflara göre sıralanmıştır. (The Story of Robert College at Constantinople, s. 10).

Tablo 1

Kuruluş Yıllarında Kolejde Okutulan Dersler

\begin{tabular}{ll}
\hline & İngilizce \\
& Anadil \\
& Temel düzeyde Mantık ve Aritmetik \\
& Güzel Yazı \\
& Coğrafya \\
\hline & Ingilizce \\
& Anadil \\
2. Yıl: İkinci Hazırlık Sınıfı - $\mathbf{6}$ ders & Fransızca, Almanca/ Türkçe \\
& Yüksek Aritmetik \\
& Coğrafya \\
& Çizim
\end{tabular}




\begin{tabular}{|c|c|}
\hline 3. Yıl: İkinci Taze (Freshmen) Sınıfı - 8 ders & $\begin{array}{l}\text { İngilizce } \\
\text { Anadil } \\
\text { Fransızca, Almanca/ Türkçe } \\
\text { Cebir } \\
\text { Geometri } \\
\text { Coğrafya } \\
\text { Tarih } \\
\text { Çizim }\end{array}$ \\
\hline 4. Yıl: Taze (Freshmen) Sınıfı - 10 ders & $\begin{array}{l}\text { İngilizce } \\
\text { Anadil } \\
\text { Fransızca Almanca, Türkçe/Farsça } \\
\text { Zooloji } \\
\text { Fizyoloji } \\
\text { Botanik } \\
\text { Geometri } \\
\text { Yüksek Cebir } \\
\text { Tarih } \\
\text { Latince Gramer ve Okuma }\end{array}$ \\
\hline $\begin{array}{l}\text { 5. Yıl: İkinci Yıl (Sophomorel Akıllı Aptal) Sınıfı } \\
\text { - } 12 \text { ders }\end{array}$ & $\begin{array}{l}\text { Retorik } \\
\text { Shakspeare } \\
\text { Fizik } \\
\text { İnorganik Kimya } \\
\text { Trigonometri } \\
\text { Araştırma (Surveying) } \\
\text { Analitik Geometri } \\
\text { Tarih } \\
\text { Anadil } \\
\text { Latin, Caesar, Sallust, Virgil } \\
\text { Fransızca Almanca, Türkçe/Arapça } \\
\text { Eski Ermenice, Yunanca /Slavca } \\
\text { Pedagoji Üzerine Dersler } \\
\text { Sanat Üzerine Dersler } \\
\text { Biyoloji Üzerine Dersler } \\
\text { Ticaret Hukuku Üzerine Dersler }\end{array}$ \\
\hline 6. Yıl: Küçükler (Junior) Sınıfı -15 ders & $\begin{array}{l}\text { İngiliz Edebiyatı } \\
\text { Mantık } \\
\text { Hıristiyanlığın Delaleti } \\
\text { Parlamenter Hukuk } \\
\text { Organik Kimya } \\
\text { Analitik Kimya } \\
\text { Mineraloji } \\
\text { İnşaat Mühendisliği } \\
\text { Calculus } \\
\text { Kütüphanecilik } \\
\text { Tarih } \\
\text { Anadil } \\
\text { Latin, Cicero, Tacitus } \\
\text { Fransızca Almanca, Türkçe/Arapça } \\
\text { Eski Ermenice, Yunanca /Slavca }\end{array}$ \\
\hline
\end{tabular}




\begin{tabular}{ll}
\hline & Psikoloji \\
& Ahlak \\
7. Yıl: Kıdemliler (Senior) Sınıfı - 14 Ders & Jelsefe Tarihi \\
& Jeoloji \\
& Astronomi \\
& Medeniyet Tarihi \\
& Uluslararası Hukuk \\
& Anadil \\
& Fransızca/Almanca \\
& Antropoloji Üzerine Dersler
\end{tabular}

Kolejde okutulan derslere bakıldığında, başlangıç yıllarında daha hafif olan müfredatın giderek ağırlaşıp çeşitlendiği, ilk söylenecek noktadır. Başlangıç yıllarındaki dil ağırlıklı eğitimden, sonraki yıllarda dile ilaveten, fen ve sosyal bilimlere kayıldığı, bu alanların alt dallarına dair derslerin okutulduğu ikinci tespitimizdir. O dönemde mevcut olan bilim dallarının tamamı Kolej müfredatına dahil edilmiştir. Böylelikle, öğrencilerin her konuda bilgi ve fikir sahibi olmaları sağlanmıştır. Neticede, böylesine kapsamlı bir müfredat ve 7 yıl gibi uzun süren bir eğitimle Kolej öğrencilerinin donanımının mükemmel olması ve üst düzey görevlere talip olacak bilgi ve beceriye sahip olmaları hedeflenmiştir. Öyle de olmuş, Kolejin ilk dönemlerinde, mezunların yanı sıra, mezun olamadan okulda eğitim alan öğrenciler bile, içinde yaşadıkları toplumda üst düzey görevlere gelmişlerdir (The Story of Robert College at Constantinople, s. 9)

\section{Kolej Mezunları}

Kolej, Eylül 1863'de, İngiliz ve Amerikan dört öğrencisi ile boğaza nazır, uzun süredir eğitim için kullanılan American Board'a ait bir binada eğitime başlamıştır. Yeni binaların inşası için Osmanlı Devleti'nden izin alınması için yedi yıl geçmesi gerekmiştir. Başlangıçtaki bu muhalefet, sadece Osmanlı devletinin değil, Cizvitler ve Fransız büyükelçisinin baskıları dolayısıylaydı. Kolejin yeni binasının temel taşı, 4 Temmuz 1869 yılında Mr. Morris tarafından törenle konuldu. Dua ile başlayan açılışı, Amerikan, İngiliz, Rum ve Ermeni otoriteleri olan dokuz ayrı kişi tarafından farklı dilelrde yapılan dokuz ayrı açış konuşması takip etmiştir. (Boyajiyan, 1869: 5-24). Bina 1871'de, diğer ilave bir bina da 1873'de tamamlandı. Zaman içinde şapel, kütüphane, laboratuvar ve müze inşa edildi. 1871'de kolejdeki öğrenci sayısı 170 iken, 1873'e gelindiğinde bu sayı 216’ya yükselmiş; on altı ayrı 
milletten, farklı din ve bölgelerden müteşekkil bir öğrenci grubu oluşmuştu. Türk öğrencilerin Kolej'e teveccühü oldukça geç bir dönemde başlamış, ilk Türk mezununu ancak 1903 yılında, kuruluşundan kırk yıl sonra vermiştir. 1905'de Kolej'de on², 1907'de ise yirmi civarında Türk öğrenci bulunmaktadır ki, ancak bu tarihlerden sonra Kolej Türkler için popüler olmaya başlamıştır (Washburn, 1909: 299).

Bu dönemde belki de en büyük meydan okuma Ermeni dini otoritelerinden gelmiş, Kolejin din ve ahlak eğitimini tamamılla bırakması ve sadece laik eğitime odaklanması istenmişti. Kolej'in dini eğitimi hiç bir zaman mezhepsel ve ayrılıkçı olmamış, İncil'den başka bir kutsal kitap okutulmamış, herhangi bir öğrencinin dinine karşı bir eleştiri de yapılmamıştı. Kolej, kuruluşundan itibaren Tanrı'ya odaklanmış, ibadete temellenmiş ve inanç üzerine inşa edilmiş; moral ve entelektüel eğitimin birbirinden ayrılmaz olduğu prensibine dayanmıştı. Kolej'de öğretilen ahlaki değerler herkes, hatta Müslümanlar tarafından da takdir edilmiş, ilerleyen dönemlerde oğullarını göndermekte bir çekince oluşturmamıştır. Mücadeleyi Kolej kazanmış ve eleştirenler de, bir süre sonra, kolejin en büyük destekçisi olmuşlardır. Bu esnada Osmanlı-Rus Savaşı (1877-1878) devam ediyordu. Anadolu'da kıtlık baş göstermiş, Balkanlardaki en zengin topraklar kaybedilmiş, Avrupa'da yeni krallıklar kurulmuş, milliyetçilik akımı yükselerek yeni milletlerin dünya sahnesine çıkmasına zemin hazırlamıştı. İstanbul'da kıtlık ve salgın hastalıklar baş göstermiş ve sadece koleradan yedi yüz bin kişi ölmüştü. Rus ordusu İstanbul surlarına kadar dayanmış; şehre akın eden üç yüz bin sivil sığınmacı ve başıboş asker sokaklarda terör estirmiş, salgın hastalıklar yayılmıştı (Origine and History of Robert College, s. 4-5). İstikrar ve zenginliğin yerine, şehir giderek fakirleşiyor ve sıkıntıya düşüyordu. Bu sebeple 1878 yılında öğrenci sayısı 128'a düştü. Hâlbuki üç yıl önce, 1875 yılında 208 idi (bkz. Tablo 1). Fakat bütün bu olumsuz şartlara rağmen kolej istikrarlı bir gelişme çizgisi yakalamıştı. Barış ve huzurun sağlanmasına katkıda bulunmaya çalışırken, Kolej bir yandan da, Tanrı'ya hizmet etmek adına, yeni yükselen milletlerin gençlerini destekliyor, onlara farkındalık ve bilinç aşılıyordu. Bu tutumu sayesinde pek çok milletin sempati, takdir ve güvenini kazanmıştı. Giderek artan ve Doğu'daki Hıristiyan kiliselerini tehdit eden ateizm dalgasına, Tanrıya inanan gençler yetiştirerek karşı koyuyordu.

\footnotetext{
${ }^{2}$ Bu dönemde 10 kişilik Türk öğrenci grubunun yanı sıra Kolejde, 171 Rum, 97 Ermeni, 34 Bulgar, 8 İngiliz, 7 Yahudi, 3 Amerikan, 8 diğer milletler (her birinden ikişer kişi olmak üzere, Macar, Rus, İtalyan, Romanyalı) ve 4 diğer milletler (her birinden birer kişi olmak üzere Arap, İranlı, Fransız, Levanten) bulunmaktadır. Report of the President and Faculty to The Trustees, 1905, s. 4. Bahsedilen Rapor, Hathi Trust, University of Illinois Kütüphanesi Dijital Arşivi'nden ulaşılmıştır. Raporlar bir seri halinde, yılda bir defa olmak üzere, 1889- 1921 yılına kadar olan dönemi kapsamaktadır. Atıfta bulunulan rapora takip eden İnternet adresinden de ulaşılabilir: http://hdl. handle.net.2027/nyp.
} 
Çeşitli millet ve dinlerden çok sayıda öğrenciyi bir arada tutmak ve her birinin taleplerine uygun bir eğitim vermek pek de kolay bir iş değildi. Kolej yöneticilerinin de başlangıçta bu konuda fazla bir fikri yoktu. Fakat önce, okulun müfredatına odaklanıldı: İngilizce eğitim dili olarak seçildi. İngilizce, Osmanlı milletler topluluğundaki herkese eşit derecede uzak, herkesin anlaşabileceği ortak bil dildi. Eğitime dâhil edilecek branşlar ve okutulacak derslerin kapsamı birinci sınıf eğitim verecek şekilde düzenlendi. Hocaları da kendini mesleğine adamış başarılı kişiler arasından titizlikle seçildi. Okyanus ötesi, uzak bir dünyada açılan bir okulun başarılı olma şansı, ancak bu tür kişilerle mümkün olabilirdi. Kolejin idarecileri, bunun çok farkındaydı. Kolej mezunlarının diplomaları, kısa sürede Avrupa'da kabul gördü ve buradaki üniversitelere giderek iyi derecelerle mezun oldular. Kolejde alınan eğitimin pratik ve pragmatik olması ve gerçek hayatta kullanılabilir olması, mezunlarını ön plana geçirdi, üst düzey pozisyonları ve önemli meslekleri icra etmelerini sağladı. Kolej İngiltere, Almanya ve Rusya'dan övgü alıyordu; bu da gelişmesine olumlu katkılar sağladı.

Kolej, en başından itibaren, inancın eseriydi. Koleji kuranların mücadelesi ve özverisine dayanıyordu. Christopher Robert, maddi ve manevi anlamda büyük çaba göstermiş ve fedakârlıklarda bulunmuş, yakınlarının ifadelerine göre, bu onun ömrünü azaltmıştı. Hamlin ise, hayatının en güzel yıllarını; bilgi, tecrübe ve enerjisinin de, en iyisini vermişti. 1880 yılında Christopher Robert vefat edince, Kolejin başkanı Amerika'ya döndü ve kolejin ihtiyaçları için 270.000 dolar bağış toplamak için iki yıl uğraştı. Fakat ancak 60.000 Dolar toplayabildi (Robert College of Consantinople (1862-1890), s. 5). Christopher Robert'in vefatından sonrası için yaptığı bağışlarla beraber, kolej ancak temel ihtiyaçlarını karşılayabiliyordu. 1882 yılında, Kolej en fakir zamanını yaşıyordu. Öğrencilerden gelen gelirler de azalmış, ülkede baş gösteren sıkıntılar Koleji de etkilemiş ve bu yılda sadece 9 öğrenci mezun olmuştu (bkz. Tablo 3-A).

Kolejin eğitim verdiği ilk yıllarda, çok az sayıda öğrenci derslerini tamamlayıp mezun olmuştu (bkz. Tablo 3-A). Öğrencilerin aileleri, uzunca bir süre eğitim almanın önemini o dönemlerde henüz kavrayamamışlardı. Çoğu öğrenci, mezun olmayı hedeflemeyerek Koleje kaydolmuştu. Fakat mezunların sayısı istikrarlı biçimde artıyordu. Kolej eğitimi 2 yıl hazırlık 5 yıl lise olmak üzere 7 yıldı. Buna mukabil, öğrenciler Kolejde ortalama 3 yıl, yani yarısından daha az zaman geçiriyorlardı. TABLO 3-A ve 3-B'de görüldüğü üzere, kurulduğu 1863 yılından 1907 yılına kadar Kolej'e 8.545 öğrenci kaydolmuştur. Bu öğrencilerden ancak 464'ü, bu dönemde (1863-1907) Kolejden mezun olmuştur. Bu, yaklaşı \% 5.4'e 
tekabül etmekte ve oldukça düşük bir mezuniyet oranına işaret etmektedir. Rakamlar tersinden okunduğunda, 8.545 öğrenciden 8.081'inin mezun olamadığı görülür. Bu, öğrencilerin \% 94,6'sına tekabül etmekte ve oldukça yüksek bir rakama ulaşarak, mezun olamadan Kolejden ayrıldıkları anlamına gelmektedir. Bu rakamları daha ileri götürmek, diğer bir ifadeyle mezun olamayanların hangi işlerle uğraştığını takip etmek bu dönem için mümkün değildir.

Fakat iyi pozisyonları işgal ettikleri ve içinde yaşadıkları toplumda öncü kişiler olduğu tahmin edilmektedir. Mezunlar ise, Osmanlı İmparatorluğu'nun son dönemlerinde ve yeni devletlerin kurulmasında önemi roller oynamışlardır. Özellikle, Bulgaristan'da en üst düzey devlet makamlarını işgal etmişler, ülkelerinin Osmanlıdan kopmasına, entelektüel ve politik yönlerden gelişmesine katkıda bulunmuşlardır. Öyle ki, 1871 yılı mezunu beş Bulgar öğrenci, Geşav, Panaretov, Stoilov, Slaveikov ve Tapçileştov, ilerleyen yıllarda belediye başkanı, parlemento üyesi, büyükelçi, bakan ve başbakan olarak yeni kurulan Bulgaristan'a hizmet etmişlerdir. Aşağıda Tablo 2'de Mezunlarının Mesleki Dağılımları verilmiştir (Alumni Statistical Information, s. 20).

Tablo 2

Kolej Mezunlarının Mesleki Dağılımları (1863-1890)

\begin{tabular}{lr}
\hline \multicolumn{1}{c}{ Meslekler } & f \\
\hline Tüccar ve Banker (dünyanın her yerinde) & 75 \\
Öğretmen (Profesör ve başkanlar dahil) & 71 \\
Devlet memuru (çoğu üst düzey) & 46 \\
Doktor & 24 \\
Hukukçu & 22 \\
Subay & 17 \\
Hakim & 12 \\
Din adamı & 10 \\
Yazar & 10 \\
Mühendis & 5 \\
Toplam & 292 \\
\hline
\end{tabular}

1863-1890 yılları arasındaki mezunların mesleki dağılımları Tablo 2'de gösterilmiştir. Toplam 292 olarak gösterilen meslek sahiplerinin fazla olmasının sebebi, bir kişinin birden fazla mesleği icra emesidir. Tabloda görüldüğü üzere, en fazla sayıda mezunun tercih ettiği meslek tüccar ve bankerliktir. Bunu, öğretmenlik ve devlet memurluğu takip etmekte; doktor, hukukçu, subay ve din adamı sırasıyla ardından gelmektedir. Yazar ve mühendis ise en alt sırayı işgal etmektedir. Tablo genelde değerlendirildiğinde para, eğitim ve devletle ilgili mesleklerin en fazla tercih edilenler olduğu görülür. \%65.7 ye ulaşan oranıyla üst gruptaki 
bu üç meslek, toplumsal değişimi sağlamanın araçlarını bünyesinde barındırmaktadır. Diğer yedi meslek mensuplarının oranı ise, ancak \%34.3'e ulaşmakta ve genelde doktorluk, din adamı, hukukçu gibi topluma hizmet sektöründeki meslekler olduğu görülmektedir. Her iki grup karşılaştırmalı olarak değerlendirildiğinde, bahsettiğimiz üzere, ilki toplumu değiştirmekle ilgili iken, ikincisinin topluma hizmetle ilgili olması, manidar ve okulun misyonuyla ilgili olduğunu akla getirmektedir. Kolejin bir misyoner mektebi olması, bu neticeyi desteklemekte ve maksadına ulaştığı sonucunu çıkarmamıza yol açmaktadır (Kocabaşoğlu, 2000, s. 18).

Kolejde 1890'lı yıllarda, on yedi ayrı milletten öğrenci bulunmaktadır: Amerikan, Ermeni, Bulgar, Kafkası, Hollandalı, İngiliz, Fransız, Alman, Rum, İtalyan, Yahudi, Rus, Sırp, İranlı, Romanyalı, Suriyeli ve Türk. Bu milletler arasında ise en fazla sayıdaki öğrenci Ermeni, Bulgar ve Rumdur. Osmanlıdan Cumhuriyete, kuruluşundan 1928 yllına kadar değerlendirildiğinde, Kolejde 28 farklı milletten öğrencinin eğitim aldığı görülür (Herkül, 2013, s. 156). Kolejin bu çok milletli yapısı, bir misyoner okulu olmasına rağmen "din" den ziyade "dil” eğitimi ön plana geçirmekte, bütün öğrencilerin iyi bir dil eğitimi almalarını gerekli kılmaktadır. Bu sebeple, dil eğitiminin ağırıklı olarak verildiği hazırlık sınıfı 2 yıl sürmektedir. Diğer bir ifadeyle, 7 yıl süren Kolej eğitiminin ilk 2 yılı öğrencilerin ana dilinin ve İngilizcenin öğretimine ayrımıştır. Öğrencilerin Kolej'de İngilizceyi en iyi şekilde öğrenmeleri en önemli kuraldır. Bunu bir Avrupa dili, Latince ve kendi dilleri takip etmektedir. Neticede, bir öğrenci dört dili en iyi şekilde bilmek zorundadır. Bu, filoloji temelli, Amerikan tarzı eğitimin bir niteliğidir. Aşağıda kolej mezunlarının milliyetleri ve sayıları Tablo 3 A ve 3 B'de verilmştir (Washburn, 1909: 306). 
Tablo 3-A

1864-1887 Yılları Arasında Kayıtlı ve Mezun Öğrencilerin Yıllara ve Milletlere Göre Dağııımı

\begin{tabular}{|c|c|c|c|c|c|c|c|c|c|c|c|}
\hline \multicolumn{7}{|c|}{ KAYITLI ÖĞRENCI } & \multicolumn{5}{|c|}{ MEZUN ÖĞRENCI } \\
\hline $\bar{\Sigma}$ & 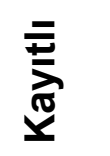 & $\begin{array}{l}\bar{E} \\
\bar{N}\end{array}$ & 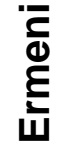 & $\begin{array}{l}\frac{\bar{\sigma}}{\bar{\Xi}} \\
\frac{\bar{\Xi}}{3}\end{array}$ & $\sum_{\mathcal{x}}^{\xi}$ & 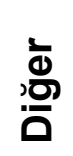 & 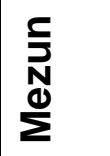 & 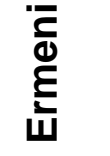 & $\frac{\bar{\pi}}{\frac{\bar{\sigma}}{\bar{n}}}$ & $\underset{\widetilde{z}}{\underline{x}}$ & 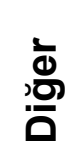 \\
\hline 1 & 20 & 16 & 0 & 0 & 2 & 18 & 0 & & & & \\
\hline 2 & 28 & 25 & 1 & 1 & 4 & 22 & 0 & & & & \\
\hline 3 & 51 & 44 & 20 & 9 & 6 & 16 & 0 & & & & \\
\hline 4 & 96 & 76 & 19 & 13 & 18 & 39 & 0 & & & & \\
\hline 5 & 102 & 79 & 14 & 16 & 33 & 34 & 2 & 1 & 1 & 0 & 0 \\
\hline 6 & 95 & 73 & 11 & 41 & 17 & 23 & 6 & 0 & 5 & 0 & 1 \\
\hline 7 & 96 & 66 & 35 & 38 & 22 & 25 & 1 & 1 & 0 & 0 & 0 \\
\hline 8 & 143 & 98 & 35 & 41 & 33 & 34 & 5 & 0 & 5 & 0 & 0 \\
\hline 9 & 218 & 164 & 80 & 40 & 34 & 64 & 8 & 0 & 6 & 1 & 1 \\
\hline 10 & 257 & 189 & 98 & 38 & 48 & 73 & 1 & 0 & 1 & 0 & 0 \\
\hline 11 & 237 & 172 & 87 & 43 & 43 & 64 & 5 & 0 & 5 & 0 & 0 \\
\hline 12 & 208 & 163 & 55 & 45 & 48 & 60 & 11 & 3 & 7 & 1 & 0 \\
\hline 13 & 191 & 152 & 54 & 33 & 39 & 65 & 15 & 7 & 7 & 1 & 0 \\
\hline 14 & 135 & 98 & 43 & 42 & 14 & 38 & 14 & 6 & 5 & 2 & 1 \\
\hline 15 & 128 & 93 & 35 & 50 & 11 & 32 & 8 & 3 & 3 & 1 & 1 \\
\hline 16 & 162 & 111 & 50 & 54 & 32 & 26 & 11 & 5 & 6 & 0 & 0 \\
\hline 17 & 209 & 149 & 74 & 77 & 27 & 31 & 7 & 3 & 4 & 0 & 0 \\
\hline 18 & 232 & 158 & 85 & 89 & 28 & 23 & 12 & 2 & 9 & 1 & 0 \\
\hline 19 & 259 & 173 & 94 & 105 & 24 & 37 & 9 & 4 & 5 & 0 & 0 \\
\hline 20 & 243 & 165 & 83 & 110 & 26 & 24 & 10 & 4 & 5 & 1 & 0 \\
\hline 21 & 215 & 142 & 82 & 91 & 29 & 13 & 22 & 7 & 14 & 1 & 0 \\
\hline 22 & 173 & 115 & 63 & 71 & 28 & 11 & 15 & 4 & 9 & 1 & 1 \\
\hline 23 & 182 & 120 & 64 & 71 & 37 & 10 & 20 & 8 & 12 & 0 & 0 \\
\hline 24 & 182 & 130 & 53 & 70 & 36 & 23 & 26 & 10 & 13 & 3 & 0 \\
\hline
\end{tabular}

Tablo 3-B

1879-1907 Yılları Arasında Kayıtlı ve Mezun Öğrencilerin Yıllara ve Milletlere Göre Sayısı 


\begin{tabular}{|c|c|c|c|c|c|c|c|c|c|c|c|}
\hline \multicolumn{7}{|c|}{ KAYITLI ÖĞRENCILLER } & \multicolumn{5}{|c|}{ MEZUN ÖĞRENCİLER } \\
\hline $\bar{\Sigma}$ & $\underset{\bar{X}}{\bar{x}}$ & $\frac{\bar{E}}{\bar{N}}$ & 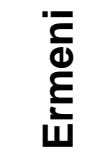 & $\frac{\frac{1}{0}}{\frac{0}{3}}$ & 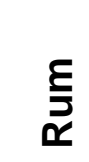 & 高 & 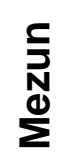 & & $\frac{\frac{1}{0}}{\frac{0}{3}}$ & $\underset{\underline{\boldsymbol{\alpha}}}{\underline{\boldsymbol{\varepsilon}}}$ & 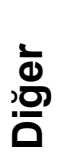 \\
\hline 25 & 170 & 113 & 55 & 60 & 33 & 22 & 28 & 12 & 15 & 1 & 0 \\
\hline 26 & 158 & 104 & 43 & 52 & 33 & 30 & 11 & 3 & 3 & 4 & 1 \\
\hline 27 & 162 & 104 & 47 & 45 & 41 & 31 & 8 & 4 & 3 & 1 & 0 \\
\hline 28 & 159 & 104 & 59 & 41 & 39 & 20 & 5 & 4 & 1 & 0 & 0 \\
\hline 29 & 194 & 130 & 70 & 52 & 47 & 25 & 8 & 4 & 3 & 1 & 0 \\
\hline 30 & 203 & 143 & 73 & 69 & 46 & 24 & 13 & 3 & 6 & 3 & 1 \\
\hline 31 & 200 & 123 & 68 & 44 & 65 & 23 & 21 & 8 & 6 & 4 & 3 \\
\hline 32 & 205 & 116 & 63 & 36 & 80 & 26 & 15 & 5 & 6 & 3 & 1 \\
\hline 33 & 221 & 132 & 69 & 37 & 92 & 23 & 6 & 2 & 3 & 1 & 0 \\
\hline 34 & 200 & 130 & 61 & 38 & 77 & 24 & 14 & 4 & 5 & 4 & 1 \\
\hline 35 & 250 & 154 & 87 & 49 & 88 & 26 & 14 & 2 & 6 & 4 & 2 \\
\hline 36 & 292 & 173 & 105 & 45 & 108 & 34 & 13 & 4 & 3 & 5 & 1 \\
\hline 37 & 297 & 176 & 108 & 39 & 112 & 38 & 18 & 8 & 2 & 5 & 3 \\
\hline 38 & 311 & 182 & 108 & 34 & 127 & 42 & 11 & 1 & 4 & 5 & 1 \\
\hline 39 & 308 & 181 & 98 & 29 & 131 & 61 & 13 & 6 & 2 & 4 & 1 \\
\hline 40 & 318 & 190 & 101 & 28 & 145 & 45 & 19 & 6 & 7 & 5 & 1 \\
\hline 41 & 320 & 188 & 94 & 23 & 168 & 35 & 17 & 6 & 1 & 9 & 1 \\
\hline 42 & 342 & 222 & 97 & 34 & 171 & 40 & 10 & 5 & 1 & 4 & 0 \\
\hline 43 & 373 & 257 & 88 & 37 & 195 & 53 & 12 & 6 & 0 & 6 & 0 \\
\hline
\end{tabular}

Osmanlı devleti sınırları dâhilinde kurulan yabancı misyoner okullarına MüslümanTürk çocukların da kaydolmasına izin veren veya yasaklayan bir kanun, talimatname vs. mevcut değildir. ${ }^{3}$ Yabancı okulların Müslüman Türk öğrenciler arasında yaygın olması ancak 20. yüzyılın sonlarına rastlar. Bu da çoğunlukla iyi bir yabancı dil eğitimi vermelerinen ve mezunlarının üst düzey pozisyonlara gelmelerindendir. Çocuklarını bu tür okullara gönderenler de zaten Osmanlı elit tabakasına mensup kişilerdir ve sayıları da fazla değildir. Yabancı okullardan mezun olan ilk Müslüman Türk olarak, 1901 yılı American College for Girls (Robert Kolej'in kız kısmı) mezunu Halide Edip Hanım ve Tevfik Paşa'nın kızı Gülistan Hanım bilinmektedir (Kılıç, 2005, ss. 250-280). Robert Kolej’den ilk Türk öğrenci Hüseyin Hulusi Pektaşın 1903 yılın da mezun olması da, ihtiyatla yaklaşılan ve daha tarafsız olarak

\footnotetext{
${ }^{3}$ Türk çocuklarının yabancı okullara gitmesini yasaklayan tek uygulama, Cumhuriyet döneminde 1931 yılında yapılan düzenlemedir. Bu düzenlemeyle, Türk öğrencilerin yabancı okulların ilkokul bölümlerine kayıt yaptırması yasaklanmıştır. Bu konuda bkz. Ayten Sezer, “Atatürk ve Türkiye'deki Misyoner Okulları”, Türkler, Cilt 17, Yeni Türkiye Yayınları, Ankara, 2002, s. 826.
} 
Kabul edilen Robert Kolej'in bile Türkler arasında ancak 1900'lerin başlarında yaygınlaşmaya başladığı şeklinde yorumlana bilir (Yıldız, 2011: 56).

O dönemlerde faaliyet gösteren yabancı okullar arasında Türklerin en çok tercih ettiği, Amerikan okulları olmuştur. Bu, büyük ölçüde Amerika'nın çok uzakta olması, Osmanlı topraklarında ayrımcılık faaliyetlerinden ziyade birleştirici rol oynamaya aday olmasından, bu tutumunu eğitim ve diğer konulardaki faaliyetlerine yansıtmasından kaynaklanmıştır. Okul kayıtları incelendiğinde, genel intiba itibarıyla, Osmanlı döneminde, başta Ermeni, Rum ve Bulgar olmak üzere, daha ziyade gayri Müslimler Koleje devam ederken, Cumhuriyet döneminde Türk öğrencilerin ağır bastığı görülmektedir.

Okulun eğitime başladığı 1863 yılında sadece dört öğrencisi vardır: Julius Robert Millingen, Edwin Millingen, David Henry Porter ve John Marton (Toprak, 2012, s 383.). Bir yıl sonra 1864 yılında öğrenci sayısı 20’ye çıkmış; 1867-1868 yılında 100 yeni öğrenci kaydolmuştur. 1874-1875 yıllarında ise ilk defa olarak 6 Türk öğrenci kaydolmuştur (Kocamanoğlu, 1999, s. 365). 1878'de Koleje kayıtlı öğrenci sayısı 162, 1902 yılında ise 318'dir (bkz TABLO 3-B) (Ulusoy, 2005, s. 64). Zaman ilerledikçe kayıtlı öğrenci sayısında hızlı artış gözlenmiştir. Öyle ki, 1903'de Kolej'de toplam 325 öğrenci eğitim alırken (Soysal, 2013, s. 98), otuz yıl sonra 1933 yılında bu sayı 596'ya yükselmiştir (Yazıcı, 2010, s. 35.). Bu esnada, uzun süren savaşlar yaşandığı, Osmanlı İmparatorluğu'nun yıkılarak yenine ulus devletlerinin kurulmasıyla öğrencilerin ait olduğu milletlerin Osmanlıdan ayrıldığı düşünülürse, sayının ilgili dönem için makul bir miktarda olduğu görülür.

\section{Kolej Meşhurları}

Kolej 1868 yılında ilk mezunlarını vermiştir. Bunlar, Bulgar ve Ermeni kökenli iki öğrencidir (bkz Tablo 3-A). 1875 yılında ise, 7 Bulgar, 7 Ermeni ve 1 Rum olmak üzere 15 mezun vermiştir (Ulusoy, 2005, s. 38). İlk Türk öğrenci, Hüseyin Hulusi, Pektaş, Kolejin kuruluşundan kırk yıl sonra, 1903 yılında mezun olmuştur. 1915-25 yılları arasında Kolejden sadece 13 Türk öğrenci mezun olmuş, bu sayı 1926-38 yılları arasında 174'e çıkmıştır. 1931 yılında Kolejin toplam mezun sayısı 981 öğrencidir (Toprak, 2003, s. 157). 1931 yılında kolejin toplam mezun sayısı 981 öğrencidir. Bu rakamlar beraber değerlendirildiğinde, Cumhuriyetin ilk yıllarında Türk öğrenicilerin. 1/5'den daha az daha az oranda olduğu, artışın ancak 1930'lu yılların sonundan itibaren yükselişe geçtiği görülmektedir. Öyle ki, 1911-1920 yılları arasında Kolej'de eğitim gören Türk öğrencilerin oranı \%4 iken, 1930-1938 yılları arasında bu oran \%53'e yükselmiştir (Milas, 2013: 164-165). Bu istatistikler değerlendirildiğinde, Kolejin Osmanlı döneminde ağırlıklı bir Hıristiyan okulu olduğu, 
Cumhuriyet dönemine gelindiğinde ise Türk öğrencilerin giderek arttığı, ağırlık kazanmalarının ise 1930'lu yılların sonuna tesadüf ettiği görülür.

Çok milletli yapıdaki kolejden en çok istifade edenlerin Bulgarlar olduğu görülür. Öyle ki, kuruluşundan 1903 yılına kadar Bulgar öğrenciler çoğunluktadır ve sayıları 195 olarak tespit edilmiştir (Yazıcı, 2011: 61). Kolejden mezun olan ilk beş Bulgar öğrencinin Bulgaristan'da başbakanlık yaptığı ve Bulgar kabinelerinin en az birinde Robert Kolej mezunu olduğu bilinmektedir. Kolej'den mezun olan Türk öğrenciler de, Osmanlıda ve Türkiye'de ilk olmuş ve önemli pozisyonlarda yer almıştır. ${ }^{4}$

Robert Kolej, 16 Eylül 1863 yılında dört öğrenci ile öğrenime başladıktan ancak kırk yıl sonra, 1903 yılında, ilk Türk öğrenci mezun olmuştur. Bunu sebebi, başlangıçta, Osmanlı hükümetinin Türk öğrencilerin yabancı okullarda okumasını kesinlikle yasaklamasıdır. Kolejin, Osmanlı milletler ailesinin üyelerine eşit mesafedeki duruşu ve eğitim odaklı anlayışı, zaman içerisinde Müslümanlara güven telkin etmiş ve Türk aileler de çocuklarını Koleje kaydettirmeye başlamışlardır. Savaş yıllarının araya girmesiyle, Osmanlı döneminde Türklerin Kolejden istifadesinin minimum düzeyde, gayri Müslümlerin ise maksimum düzeyde olduğu söylenebilir. Kolejden Türklerin istifade etmeye başlamasının ancak Cumhuriyetin ilk yıllarına tesadüf ettiği görülmektedir.

Kolej, kuruluşundan itibaren müfredatını ve öğretim yöntemlerini sürekli yenileyerek, ülkenin ihtiyaçlarını karşılamaya yönelik eğitim vermeyi kendisine ilke edinmiştir. Bu kapsamda 1912 yılında, kolej bünyesinde bir mühendislik okulu, yani akademi açılmıştır. Ülkedeki mevcut mühendislik mektepleri askeri amaca yönelik iken, Kolejin mühendislik mektebi inşaat, elektrik, makina ve maden mühendisliği alanlarında sivil amaca yönelmiştir. Kolej, Türkiye Cumhuriyeti'ne en büyük katkısını, Osmanlıdan kalma geleneksel tarım toplumunu modern sanayi toplumuna dönüştürmede rol oynayarak yapmıştır. ${ }^{5}$ Bunu da,

\footnotetext{
${ }^{4} 1863$ yılında kuruluşundan Boğaziçi Üniversitesi'ne dönüştüğü 1975 yılına kadar olan süreçte Kolejden mezun olan Türk öğrenciler üzerine, makalenin yazarının yürütücüsü olduğu TÜBiTAK destekli bir araştırma projesi yürütülmektedir: Osmanlıdan Cumhuriyete Yabancı Okullar: Robert Kolej'de Okuyan Türk Öğrenciler Üzerine Bir Prosopografi Çalışma (1863-1971), Proje No: 113K135). Proje kapsamında bir doktora bir de master tezi yapılmaktadır. Proje, Kasım 20016 yılında tamamlandığında mezunlarla ilgili daha kesin bilgilere sahip olunacaktır. Halen proje kapsamında veri girişi yapılmaktadır. Projenin istatistikleri hazır olmadığı için bu çalışmada kullanılmamış, arşiv kaynakları, raporlar ve ilgili literatürdeki eserleden istifade edilmiştir.

${ }^{5}$ Türkiye'deki Amerikan Okullarının statüsü konusunda, Cumhuriyetin ilk yıllarında sıkıntılar yaşanmıştır. Yeni kurulan devlet, sınırları dahilindeki eğitim kurumlarını kontrol altına almak istemiş ve bu konuda sınırlamalar getirmiştir.
} 
Cumhuriyete sağladığı yetişmiş insan gücü ve bilimsel ilerlemeye yaptığı katkılarla gerçekleştirmiştir. Cumhuriyetin kurulmasıyla, bilim, teknoloji ve endüstriyel organizasyon konularında acilen iyi yetişmiş insan gücüne ihtiyaç duyulmaya başlanmıştır. Türkiye'de hammadde, toprak, enerji ve insan gücü yeterince bol miktardadır, ancak bunların verimli bir üretime dönüşümü henüz yeterli düzeyde gerçekleşmemiştir. Bu da, bilimsel gelişmelerin endüstriyel üretime uygulanması ve iyi yönetimle mümkün olabilmektedir. Bilimsel alanda iyi yetişmiş insan gücü, sanayinin dinamik gücüdür. Fakat bilim insanları teknolojik gelişmeyi kendi başlarına gerçekleştiremezler. Onların düşüncelerini uygulamaya koyacak mühendislere ihtiyaç vardır. Bilim insanı ve mühendislerin ise, idari yetenekleri olan kimseler tarafından desteklenmesi gerekmektedir. Yapılan bilimsel icatların sanayi ürününe dönüştürülmesi ve başarılı biçimde piyasaya sunulması sürecine Kolej, Türk ekonomisinin ihtiyacı olan bilim insanı, mühendis ve idarecileri yetiştirerek katkıda bulunmuştur. Kolejin imkânları ve öğrencilerinin İngilizce başta olmak üzere birkaç yabancı dili iyi bilmeleri, onların dünya standartlarında eğitim almalarını sağlarken, en donanımlı şekilde yetişmelerini, bu suretle, standart Türk bilim insanı ve mühendislerinin önüne geçmelerini sağlamıştır.

Kolejin ilk Türk mezunu Hüseyin Hulusi Pektaş '03, 1903 mezunudur. İsmin yanında belirtilen rakam mezuniyet yılını göstermektedir. Avrupalı güçlerle Türkiye'nin geleceği hakkında pazarlık yapmaya Lozan Konferansı'na giden İsmet Paşa riyasetindeki heyette sekreter ve tercüman olarak yer almıştır. Cumhuriyetin kuruluşunun ardından, sanayileşmiş dünya ile rekabet etmesi için Türkiye'nin yetişmiş insan gücüne olan ihtiyacı bir anda artmıştı. Bu ihtiyacı gideren insanlar arasında Kolej mezunları ağırlıklı olarak yer alıyordu. Ankara, yeni kurulan Cumhuriyetin başkenti ilan edildiğinde (13 Ekim 1923), bu küçük ölçekli şehrin inşası gündeme geldi. Devlet öncülüğünde gerçekleştirilen bu geniş kapsamlı inşa planının başarıyla neticelenmesinde Kolej'den 1928, 1930 yılında mühendis olarak mezun olan Galip Rıfat Kardam'ın katkısı önemliydi. Kardam, başkentteki bakanlık binalarının, hipodrum, stadyum ve benzeri binaların yapımından sorumluydu. Başkentin inşasının ardından, Karabük Demir-Çelik fabrikası, Zonguldak limanı ve kömür ocağı yapımında yer aldı. Aşağıda, çeşitli alanlara göre Kolej mezunlarının çalıştığı sektörler ve Türkiye'ye yaptığı katkılar verilecektir (Robert College Alumni in Turkey, s. 1-7).

\section{Ülkenin Elektrikle Aydınlanması}

Diplomatik ilişkilere de yansıyan bu sorunlar hakkında bkz. Semih Bulut, Atatürk Döneminde Türkiye ABD iliş̧kileri (19231938), Atatürk Araştırma Merkezi: Ankara 2010, s. 141-160. 
I. Dünya Savaşı (1914-1918)'ndan önce Türkiye'deki belli başlı büyük şehirlerin aydınlanmasını bir Belçika şirketi üstlenmişti. Atatürk ise, bu işin Türk mühendisler ve Türk şirketler tarafından yapılması gerektiğini düşünüyordu. Bu tarihe kadar, elektrik mühendisliği eğitimi yalnızca Robert Kolej'de veriliyordu. Bu sebeple, 1916 yılı Kolej mezunu ve 1922 Robert Kolej Mühendisliği Okulu'nun ilk Türk mezunu olan Hasan Halet Işıkpınar göreve çağrıldı. İki yüzden fazla elektrik santralinin tasarlanması ve kurulumu işi Işıkpınar'a havale edildi. Etibank müdür yardımcılığı görevini yürüten Salim Öker '30 de, Türkiye'deki bütün santrallerin yöneticisi konumuna getirildi (Robert College Alumni in Turkey, s. 2).

\section{Ekonomi}

1933 yılında ekonomi uzmanlarından oluşan bir Amerikan heyetine, Türkiye'nin ekonomik intiyaçları hakkında araştırma yapmak işi havale edildi. Bu heyete yardımcı olması için Maliye Bakanlığı üç kişi görevlendirdi; Resai Ali Bengür '33, Kasım Gülek '26 ve Muzaffer Yeşim '18. Bu üç kişi de Robert Kolej mezunuydu ve ülkenin ekonomik bakımdan kalkınmasının planlanmasında önemli rol oynadılar. Muzaffer Yeşim Yurtışına giden ilk ekonomi ataşesi oldu. Kasım Gülek 1940 yılında TBMM'ye girerek politikaya atıldı ve Devlet Bakanlığı, Ulaştırma Bakanlığı ve Bayındırlık Bakanlığı görevlerini yürüttü. Uzun siyasi kariyerinde senatör oldu ve ülkesine hizmet etti. Resai Ali Bengür ise, yirmi yıldan fazla IMF (International Monetary Fund) ile çalıştı

Amerikan heyetinin önündeki Türkiye'nin ekonomisi ile ilgili en önemli soru, ne tür bir para sistemine sahip olması gerektiğiydi. Robert Kolej mezunlarından Nihat Alpar '31 ve Bülent Yazıcı '32 heyete dâhil olarak para politikalarının oluşturulmasına katkıda bulundular. Alpar, daha sonra, Washington Türk Büyükelçiliğinde mali danışman oldu, Yazıcı ise, bankacılık ve finans sektöründe kariyer yaptı (Robert College Alumni in Turkey, s. 2).

\section{Devlet Tekeli}

Cumhuriyetin ilk yıllarındaki hızlı sanayileşme programı devleti, işleri kendi yürüteceği pozisyona koyuyordu. Ayrıca, büyük çaplı işleri yürütecek araç-gereç ve sermaye birikimine sadece devlet sahipti. Bu konuda ilk intiyaç duyulan mühendisti. Bu ihtiyacı karşılayan da Robert Kolej oldu: Kenan Yalter '33 tütün eksperti oldu; Ömer Refik Yaltkaya '29 ve Hayrullah Gürtan '30, Kenan Yalter ile birlikte Devlet Tekel'inde genel müdürlük yaptılar. 
Andan Taşpınar '19 da, 1939-1943 döneminde Tekel Genel Müdürlüğünü yaptı. Tekel, daha sonra Ticaret Bakanlığı bünyesine dâhil edildi. Kolej mezunu Ahmet Cemil Conk '30 da burada ticaret genel sekreteri ve Washington ticari danışmanı olarak görev yaptı (Robert College Alumni in Turkey, s. 2).

\section{Yol Yapımı}

Türkiye ancak II. Dünya Savaşı (1939-1945)'ndan sonra modern otoyol yapım sistemine ağırlık verdi. Bu konuda tecrübesi olan ve meşhur Alaska otoyolunu inşa etmiş olan E. O. Hills'den istifade edildi. Hills'in ilk işi, bir Amerikan okulu olan Robert Kolej'den mühendisleri yol yapım programına dahil emekti. Öyle ki, Hills “Tanrıya şükür ki Robert Kolej var" demişti. Karayolları Müdürlüğü 1947'de kuruldu ve 1950 yılında ise Karayolları Genel Müdürlüğü’ne dönüştü. Kolej'in 1932 mezunu Necmi Diker 1949'da genel müdür oldu ve yine bir Kolej mezunu olan Orhan Mersinli '33'ye görevini devretti. Diker, Türkiye'yi traktör imalatı işine sokan kişiydi. Yine, artan mühendis ihtiyacı karşısında Türk hükümetini, Ortadoğu Teknik Üniversitesi'ni kurmaya ikna eden kişiydi (Robert College Alumni in Turkey, s. 2).

\section{Birleşmiş Milletler}

II. Dünya Savaşı sonunda Nisan 1945'de San Francisco'da delegeler Birleşmiş Milletler Anlaşması'nı yapmak üzere toplandığında, Türkiye'yi Kolej mezunu Hazım Atıf Kuyucak '17 temsil etmişti. Öyle ki, Suriye ve İran'ı da Robert Kolej mezunları temsil etmişti. 1947'den itibaren Birleşmiş Milletler önemli pozisyonlarına Robert Kolej mezunlarını getiriyordu. Bunlardan ilki olan Selim Sarper '17, 1947'den 1960 yılına kadar Türk delegasyonuna başkanlık etti. 1960 yılında askeri darbe yapılınca, Türkiye'ye döndü ve Dışişleri Bakanı oldu. Onu takiben Turgut Menemencioğlu '35 altı yıl süreyle dışişleri bakanlığı yaptı, akabinde Amerika, İngiltere ve CENTO’ya Büyükelçi oldu. New York'daki Birleşmiş Milletler Protokol Müdürü Sinan Korle '36 de Kolej mezunudur (Robert College Alumni in Turkey, s. 3).

\section{Bankacılık ve Finans}

Devletin büyük çaplı projelerini gerçekleştirmek üzere, farklı sektörler için farklı bankalar kuruldu. Bu bankalarda da Robert Kolej mezunları önemli görevler aldılar. 
Örneğin, Salim Öker '30 Etibank'ta, Ferdi Tuğmen '32 Denizcilik Bankası'nda önemli görevler üstlendiler (Robert College Alumni in Turkey, s. 3).

\section{Özel Sektör}

Cumhuriyetin kuruluş yıllarında kendi tekelinde olan işleri devlet, II. Dünya Savaşı'ndan, 1945 yılından sonra özel sektöre devretmeye başladı. Devletin sahip olduğu bu işleri devralan en önemli kişi Vehbi Koç'tu. Kendisi, Robert Kolej mezunu değildi. Ankara'da küçük bir tüccardı. Türkiye'nin pek çok maddeye ihtiyacı olduğunu, bunların yurtdışından ithal edilmesi gerektiğini düşündü ve Robert Kolej mezunlarından oluşan bir grup kurarak, ithalat işine girişti. Bu kişiler, Türkiye'ye lokomotiften büro malzemesine kadar her tür malzemenin ithalinden sorumlu oldular. Bunlardan biri, Amerika'da okuyan ilk Türk öğrenci olan Kenan İnal '21 idi. İnal 19 yıl Socony Vacuum tecrübesinden sonra Koç tarafından Lastik Bölümü'nün başına getirildi. Birkaç yıl sonra bu bölüm büyüdü ve İstanbul ve Ankara'da şubeleri açıldı. Ankara şubesinin müdürü Hüseyin Sermet '28 ve şirketin genel sekreteri Hüseyin Kırkbir '36 Kolej mezunuydu. Ofis Makinaları Bölümü'nün başında olan Behçet Osmanoğlu '35, Türk iş dünyasında öncü rol oynadı. 1950'li yılların sonuna doğru devlet özel sektöre üretim izni verince, Kolej mezunu Fazıl Zobu '34, Koç'un kibrit fabrikasının genel müdürü oldu. Fabrikadaki baş kimyacı İsmail Türegin '37 Kolej mezunuydu. 1966 yılında Koç, otomobil işine atılıp Anadol'u üretmeye başladığında, genel müdür Ahmet Binbir '49 Kolej mezunuydu. Anadol Fiber-glass'ın müdürü Nihat Atasagun '50 da Kolej mezunuydu. Koç şirketler grubu, Ortadoğu ve Balkanların en büyük beyaz eşya üretim fabrikasını kurduğunda, çeşitli bölümlerinde Kolej mezunlarını istihdam etti ve Fahir İlkel '43 1966 yılında şirketin genel müdürlüğünü yaptı.

Koç Şirketler grubu, altmıştan fazla şirketiyle Türkiye'de ilk holdingi 1961 yılında kurduğunda, bu fikri ilk kez, Kolejin 1951 mezunu, Vehbi Koç'un oğlu, Rahmi Koç gündeme getirmişti. Holdingin genel sekreteri ve Vehbi Koç'un kızı Suna Koç Kıraç, Kolej'in kız kısmından 1960 yılında mezun olmuştu. Koç Holding bünyesindeki Kolej mezunları oldukça fazlaydı. Vehbi Koç'un şirketinin organizasyonunda bir grup Robert Kolej mezununu istihdam etmesi ileri görüşlülüğünün, bu Ankaralı küçük tüccarın büyük bir iş adamı ve Türkiye'nin en zengini haline dönüşmesinde önemli rol oynadığı söylenmektedir (Robert College Alumni in Turkey, s. 3-4). 


\section{İlaç ve Silah Sanayii}

Türkiye'nin zenginleri arasında bulunan Nejat Eczacıbaşı 1932 yılı Kolej mezunudur. İmirli bir eczacının oğlu olan ve İstanbul'da kiralık bir apartman katında ecza laboratuvarı ile iş hayatına başlayan Eczacıbaşı, Türkiye'nin en büyük özel ilaç şirketini kurdu. Daha sonra kâğıt, tuvalet malzemeleri ve seramik üretimine geçti ve şirketi holdinge dönüştü. Topluma ve toplumun intiyaçlarına yönelmiş bir birey olan Eczacıbaşı, eğitime de ağırlık verdi ve Türk Eğitim Derneği (TED)'in kurucuları arasında yer aldı. 1950'lerin başlarında, 1935 yılı kolej mezunu Enver Yelkenci'ye ait Şark Ticaret Şirketi, fişek ürünleri ithalatı yaparken, New York'lu bir şirket tarafından fişek yapımı teklif edilince kabul etti ve on bir Kolejli arkadaşıyla beraber İstanbul'da bir fişek fabrikası açtı. Fabrikadaki çeşitli görevler için çok sayıda Robert kolej mezunu istihdam edildi (Robert College Alumni in Turkey, s. 4).

\section{İmalat ve Tekstil Sanayii}

Kolejden 1937 yılında mezun olan Yavuz Selek, Sınai Kalkınma Bankası'nda müdür olarak çalıştı ve 1950'li yılların sonlarına doğru Türkiye'deki ilk tam otomatik, mdf fabrikasını kurdu. ELKA şirketi inşaat malzemeleri üretimi yapan önemli bir şirket haline geldi ve bünyesinde kolej mezunlarını istihdam etti. 1951 yılı Kolej mezunu olan İbrahim Bodur, önce babasıyla beraber tütün işiyle uğraştı, ardından pamuk ipliği üretimine geçti. 1961 yılında seramik fabrikası açıı. Çanakkale Seramik adını alan bu fabrika ileride Türkiye'nin en büyük seramik fabrikası haline dönüştü.

Tekstil sektöründe çok sayıda Kolej mezunu yer almıştır. Bu konuda, en eski ve en büyük firma olan Mensucat Santral'in genel müdürü Ahmet Şeci Edin '47 ve Dilber Tekstil genel müdürü İbrahim Dilber '30 zikredilebilir. Dilber ailesinden dört kişi de Kolej mezunu olmuş ve şirketlerinde yönetici pozisyonunda bulunmuştur. Dört tarafı denizlerle çevrili olan Türkiye'de balıkçılık, dolayısıyla da ağ imalatı önemlidir. Kolej mezunu Feyzi Özbilen '57 Amerika Massachusetts'deki Lowell Technical Institute'de master tapmış ve Türkiye'de bu sektörde öncü rol oynamıştır. Zaman içerisinde, Türkiye'nin mühendislik potansiyeli ve mühendislerin ürettiği eşyalar artmış ve yurtdışına ihraç edilir hale gelmiştir. İhracat işinde Kolej mezunları önemli yer almıştır. Tekfen İmalat ve Mühendislik Şirketi'nin kurucuları arasında kolej mezunu Feyyaz Berker '46 bulunmaktadır. Şirkete ait Ampul fabrikasının genel müdürü Kamran Sertel '45 de Kolej mezunudur. 1955'den önce Traktör ithal edilmektedir. Bu tarihte, Ankara'da Minneapolis-Moline Fabrikası'nın kuruluşuyla, 
Türkiye'de traktör üretimine başlanmıştır. Kurucusu Kolej mezunu Vecdi Diker '32 dir. Fabrika daha sonra Türk Traktör ve Ziraat Aletleri A.Ş.'ne dönüşmüştür. British Motor Company'de İzmir'de traktör üretimine başlamıştır. Bu fabrikanın kurucusu da, Kolej mezunu Melih Özakat '48 tır. Uzun yıllar boyunca, demiryollarını devlet işletmiş, kolej mezunları, örneğin Hayrullah Gürtan '50 başmühendis olarak yer almıştır (Robert College Alumni in Turkey, s. 4-5).

\section{Bankacılık}

Kolej mezunları iki dilli olmaları sebebiyle, bankacılık sektöründe aranan kişiler olarak yer almış ve üst pozisyonlara gelmiştir. İş Bankası genel müdürlüğünü yapan Bülent Yazıcı '32 kolej mezunudur. Garanti Bankası, Kolej mezunu Tarık Koyutürk '33'ün dâhil olduğu bir grup tarafından kurulmuştur. Turgut Erdem '32, Yapı Kredi Bankası danışmanlığını yapıştır. Türkiye Sınai Kalkınma Bankası 1950 yılında Dünya Bankası tarafından, özel sektöre verilecek kredilerin akışını kontrol etmek üzere kurulmuştur. Dünya Bankası ve diğer yabancı kredi kuruluşlarından özel sektöre kredi akışını düzenlemektedir. Bu rolü dolayısıyla çok sayıda kolej mezununu istihdam etmiştir. Bankanın kurucularından Nazım Atıf Kuyucak '17 kolej mezunudur (Robert College Alumni in Turkey, s. 6).

\section{Otel ve Moteller}

Kolej mezunları Türkiye'de otel ve motel fikrini geliştirmiştir. Bunlardan biri ve en büyüğü, aralarında kolej mezunu Memduh Mopan '23'ın bulunduğu bir grup tarafından inşa edilmiştir. İzmir'deki diğer üç otel de Kolej mezunu Halil Özbaş '42, diğer ikisi de Şükrü '40 ve Haluk Kilimci '50 tarafından yönetilmektedir. Koç Şirketi'nin sahip olduğu İstanbul'daki Divan Otel'de de, ağırlıklı olarak Kolej mezunları istihdam edilmiştir (Robert College Alumni in Turkey, s. 6).

\section{Ulaşım}

İki dilli olmaları sebebiyle Robert Kolej mezunları, uluslararası ulaşım sektöründe büyük ölçüde yer almışlardır. Bunlardan biri olan Samih Şenik İstanbul'daki Pan American Havayolları'nda danışmanlık yapmıştır. Cengiz Osken' 53 ise, Şen İzmir Genel Ulaşım Şirketi'nin sahibidir (Robert College Alumni in Turkey, s. 6). 


\section{Sigortacilık}

Türkiye'deki sigorta şirketlerinin bazıları bankalara aittir, bazıları ise uluslararası sigorta şirketleri ile bağlantılıdır. Yapı Kredi Bankası tarafından kontrol edilen Halk Sigorta'nın genel müdürü kolej mezunu Ali Neyzi '46 dir. Engin Asal '52 Doğan Sigorta Şirketi ve Amerikan bağlantılı Atlantik Sigorta Şirketi genel müdürüdür. Diğer bir sigorta şirketi olan TAM'ın genel müdürü de Kolej mezunu Bedi Yazıcı '37 dir (Robert College Alumni in Turkey, s. 6).

\section{Pazarlamacılık}

Türkiye'deki ilk pazar araştırma şirketi, 1969 yılında FEVA adıyla Kolej mezunu Nezihi Neyzi '44 tarafından kurulmuştur. Türk İdare Kurumu'nun genel sekreteri, Faiz Poroy ve çalışanlarının büyük bir kısmı Kolej mezunudur. Pazarlamacııık konusunda Türkiye'deki ilk girişimciler Robert Kolejliler olduğu için, bu alandaki pek çok irili ufaklı firmada onlar istihdam edilmişleridir (Robert College Alumni in Turkey, s. 6).

\section{Sanat}

Tiyatro Kolej müfredatının haricinde bir faaliyet alanıdır. Fakat çok sayıda tiyatro sanatçısı da Kolejden yetişmiştir: Genco Erkal '57, kendi tiyatrosunun sahibi olan Engin Cezar '57 ve devlet tiyatrolarına aktör, tercüman ve direktör olarak önemli katkıda bulunmuş olan Nüvit Özdoğru '46 Kolej mezunudur (Robert College Alumni in Turkey, s. 6-7).

\section{Politika}

Kolej mezunları arasında, siyasete atılıp üst düzey politikacı olanlar da bulunmaktadır. Burada sadece en meşhurları zikredilecektir. Kolej'den bir cumhurbaşkanı ve iki başbakan yetişmiştir: 1934 yılı Kolej mezunu olan Fahri Korutürk 6. Cumhurbaşkanı olmuştur (1973 -1980). Başbakanlardan Bülent Ecevit '44 en meşhurudur. Cumhuriyet Halk Partisi genel başkanlığı görevini de yürütmüştür. Diğer başbakan ise, Kolejin orta kısmından mezun olan Naim Talu '38'dur. Başbakanlığın yanı sıra Ticaret bakanlığı da yapmıştır. 1926 yılı mezunu olan Kasım Gülek 1940 yılında TBMM'ye girerek politikaya atılmış ve Devlet 
Bakanlığı, Ulaştırma Bakanlığı ve Bayındırlık Bakanlığı görevlerini yürütmüştür. Uzun siyasi kariyerinde senatörlük de yapmıştır. ${ }^{6}$

\section{Tartışma}

Kolejde okutulan derslerde, yukarıda Tablo 1'de de görüleceği üzere, dil önceliklidir. Öyle ki, öğrenciler eğitim aldıkları yedi yıl boyunca her yıl, kendi ana dileri ve bir yabancı dili derslerde öğrenmektedir. Bu da göstermektedir ki, öğrencilere ana dileri bilinçli ve en etkili biçimde öğretilmektedir. Bunun yanı sıra bir yabancı dil de kendi ana dilleri gibi öğretilmektedir. Ayrıca, yabancı dilin kökeni olan Latinceye de programda yer verilmiştir. Dilin çok önemli olduğunu, hatta eğitim konusunda ilk sırada yer aldığını gösteren bu durum, öğrencileri ilerideki meslek hayatlarında iletişime ve düşünmeye en iyi şekilde hazırlamakla üzere konulmuştur. Çünkü dil, bir iletişim aracı olmasının yanı sıra, düşüme ve düşünceleri ifade etme aracıdır. Bu araç ne kadar iyi bilinirse o kadar iyi iletişim kurulur ve o derece iyi ve original düşünce üretilebilir. Porgramım kalan kısmı dönemde bilinen tüm bilimsel alanları kapsamaktadır: Hukuk, kimya, minaraloj, (madencilik), felsefe, jeoloji, astronomi, fizyoloji, botanic, tarih, matematik mantık, Hıristiyanlık vb. alanların dahil edilmesi, öğrencileri verilen bu orta eğitim düzeyinde mevcut alanların tümünden haberdar etme ve vizyonlarını geniişletme, her alanı göstererek, kabiliyetlerinin olduğu ve ileride kendilerini yetkin hissedecekleri alanlara yöneltmekle ilgili olmalıdır. Geniş bir yelpazede öğrenim gören öğrenciler, kendi yetenekli oldukları alanları daha kolay seçebilecek ve kendilerini keşfedebileceklerdir. Tabii ki bu söylediklerimiz derslerin adlarından yola çıkılarak yapılan değerlendirmelerdir. Daha ileri düzeyde değerlendirmenin yapıla bilinmesi için derslerin içerikleri üzerine bir çalışma yapılması, okutulan kitapların incelenmesi greklidir. Bu ise başka bir çalışmanı konusudur.

Kolejden mezun olan öğrenciler donanımlı biçimde, meslek ve özel hayatlarına atılmaktadır. Kolej'e kayıt olan öğrencilrle mezun olan öğrenciler arasında neredeyse

\footnotetext{
${ }^{6}$ Kolejden mezun olan ve siyasete atılan kişilerin listesi oldukça kabarıktır. Yukarıda sadece en meşhurları verilmiştir. Yukarıda bahsedilen ve siyasete atılan diğer şahıslar hakkında bilgi, takip eden belgede bulunmaktadır: Robert College Records, Alumni, Box no: 67, Folder No: 25, s. 1-2. Columbia University, Rare Books and Manuscripts Library, New York.
} 
uçurumun olması, kayıt olanların sadece \%5,4'ünün mezun olması, kolejin bahsettiğimiz o çok iyi eğitimini, öğrencilerin büyük bir kısmının almadığı anlamına gelmektedir ve bu doğrudur. Çok düşük sayıda öğrencinn mezun olması, bir yandan eğitimin uzun olması ve uzun eğitimin öneminin kavranamaması ile izah edilirken, diğer yandan da, dönemin sıkıntılı şartları ile ihaz edilebilir. Kolejin açıldığı ve eğitime devam ettiği dönem, İmparatorlukların yıkıldığı, ulus devletlerin kurulduğu döneme tekabül etmektedir. Öğrenciler siyasetle iç içe yaşamaktadır, bundan da uzak duramamışlardır. Dahası siyaseti yönendiren kişiler olmuşlardır. Kolej bir Hıristiyan misyoner mektebi olduğu için, Türk öğrencilerin rağbet etmesi ancak 1900'lerin başlarına tesadüf etmiştir. O sebeple, Osmanlı döneminde Kolej'den istiifade edenler çoğunlukla gayri MüsImler olmuştur. Osmanlı son dönemlerinin özgür, bir o kadar da sıkıntılı şartlarında (I.Meşrutiyet (1876-1878) ve II. Meşrutiyet (19081918) dönemleri ve Trablusgarp Savaşı (1911), Balkan Savaşları (1912-1913) ve I. Dünya Savaşı (1914-1918) kastediliyor) Türk öğrencilerden ziyade gayri Müslim öğrenciler Koleje devam etmiş ve istifade etmiştir. Ancak Cumhuriyet kurulduktan sonra Türk öğrencilerin Kolej'de artan miktarda yer almaya başladığı görülür. Cumhuriyetle beraber Kolej, Milli Eğitim Bakanlığı'na bağlanmış ve daha sıkı denetim altına alınmıştır. Misyoner okulu olma kisvesinden büyük ölçüde sıyrılan Kolej, Türk kanunlarına tabi oldukça Türk öğrencilere daha cazip gelmeye başlamıştır. İmparatorluğun dağılması ve eskiden Kolej'e devam eden milletlerin İmparatorluk sınırları haricinde kalması da, Kolej'l daha az milletli, daha ağırlıklı Türk öğrencilerin deveam ettiği bir okul haline gelmesinde etkili olmuştur. Kolej'den çok sayıda meşhur ve ilkleri gerçekleştiren öğrenci mezun olmuştur. Özellikle, Cumhuriyetin ilk dönemlerinde çeşitli alanlarda ilkleri Türkiye'ye getiren, girişimci ruhlu, dünyayı tanıyan ve dünya ile bütünleşik biçimde düşünen ve yaşıyan kişiler Kolej'den yetişmiştir. Bunlar da, tarım toplumundan oluşan Anadolu'nun Sanayi toplumuna dönüşmesi için ilk kıvılcımları çakmışlardır.

\section{Sonuç}

Genel bir değerlendirme yapıldığında, Robert Kolej mezunlarının, iki dili çok iyi bilmeleri dünyaya daha açık olmalarını sağlamış, iyi eğitim almaları ve donanımları sayesinde çoğu alanda ilk girişimcilerden olarak içinde yaşadıkları topluma katkı ve katma değer sağlamışlardır. Yabancı dil, kurucusu Cyrus Hamlin'in dediği ve ısrar ettiği gibi, "dünyaya açılan penceredir". Eğitim dili olan ingilizce okulda öğrenlen dilinin ötesine geçerek, ana dile yakın biçimde öğretilmiştir. İngilizcenin eğitim dili olarak seçilmesinin 
ardından eğitime dâhil edilecek branşlar ve okutulacak derslerin kapsamı birinci sınıf eğitim verecek şekilde düzenlenmiş, hocaları da kendini mesleğine adamış başarılı kişiler arasından titizlikle seçilmiştir. Okyanus ötesi, uzak bir dünyada açılan bu okulun başarılı olma şansı ancak bu tür kişilerle mümkün olabilirdi. 1863 yılında kuruluşundan, 1907 yılına kadar Kolej'e kayıt olan öğrencilerden çok az bir kısmının mezun olması ki bu oran \%5,4'dür, verimsizliğe işaret gibi görülebilir. Lakin bu durum kolej eğitiminin yedi yıl gibi uzun sürmesi, o dönemlerde uzun eğitimin öneminin anlaşılamaması veya Osmanlı son dönemlerinin sıkıntılı geçmesi dolayısıyla öğrencilerin Koleji bitirecek zamanlarının olmaması şeklinde yorumlanabilir. Öyle ki, bu dönemde Kolej'e devam eden öğrenciler ağırlıklı olarak gayri Müslimlerdir. Onlar da son dönemde hızla Osmanlı devleti ile bağlarını koparmakta ve kendi devletlerini kurmakta ve ona hizmet etmektedir. Mezuniyet oranının çok az olmasına ragmen, öğrencilerin Kolejde alınan eğitimin pragmatik ve gerçek hayatta kullanılabilir olması sayesinde, mezunları ön plana geçmiş, üst düzey pozisyonları ve önemli meslekleri icra etmişlerdir. Kolej eğitimi öğrencilerine ilkleri başarmaları için gerekli vizyonu kazandırmış, dünya ile bütünleşik biçimde çalışmaları, düşünmeleri ve yaşamaları için gerekli altyapıyı sağlamıştır. Bu suretle, başarılı işadamı ve siyasetçilerin yanı sıra, çok sayıda ilklere öncülük eden kişier, Kolej mezunları arasından çıkmıştır.

\section{Kaynakça}

Alumni Statistical Information, Robert College Records, Box no: 67, Folder No: 28, s. 20. Columbia University, Rare Books and Manuscripts Library, New York.

Boyajiyan, A.H. (1869). Laying of the corner stone of robert college, July 41869. Constantinople Galata.

Bulut, S. (2010). Atatürk döneminde Türkiye ABD ilişkileri (1923-1938). Ankara: Atatürk Araştırma Merkezi.

Freely, J. (2009). A bridge of culture; Robert College. Boğaziçi University. İstanbul. Hamlin, C. (2012). Robert Kolej uğrunda bir ömür. İstanbul: Dergah. 
Kılıç, S. (2005). Cumhuriyet döneminde yabancı okullar (1923-1938). Atatürk Araştırma Merkezi Dergisi, C. XXI, Sayı 61, s. 250-280. Internet aderesi: http://www.atam. gov. tr /dergi/sayi-61/cumhuriyet-doneminde-yabanci-okullar-1923-1938.

Kocabaşoğlu, U. (2000), Anadolu'daki Ameirka. Ankara: İmge.

Kocamanoğlu, E. (1999). Osmanlı döneminde Robert Kolej'de din eğitimi. Osmanlı (C. 5, ss. 359-366). Ankara: Yeni Türkiye.

Millas, H. (2013). Robert kolej öğrencileri ve etnik kimlikler, bir geleneğin anatomisi: Robert Kolej'in 150 yıll, İstanbul: İstanbul Araştırmaları Enstitüsü.

Origin and History of Robert College, Robert College Records, Box no: 48, Folder No: 22, Columbia University, Rare Books and Manuscripts Library, New York.

Report of the President and Faculty to The Trustees, 1905, s. 4. Bahsedilen Rapor, Hathi Trust, University of Illinois Library Kütüphanesi dijital Arşivinden ulaşılmıştır.

Robert College Alumni in Turkey, Robert College Records, Alumni, Box no: 67, Folder No: 28, s. 1-7. Columbia University, Rare Books and Manuscripts Library, New York. Robert College of Consantinople (1862-1890), Robert College Records, Box no: 48, Folder No: 23, s. Columbia University, Rare Books and Manuscripts Library, New York.

Robert College Records, Alumni, Box no: 67, Folder No: 25, s. 1-2. Columbia University, Rare Books and Manuscripts Library, New York.

Sezer, A. (2002). Atatürk ve Türkiye'deki misyoner okulları. Türkler (Cilt 17, ss. 820-835). Ankara: Yeni Türkiye.

Soysal, F. (2013). "Robert Kolej'in Osmanlı dönemi”, bir geleneğin anatomisi: Robert Kolej'in 150 Yılı. İstanbul: İstanbul Araştırmaları Enstitüsü.

Şişman, A. (2000). 20. Yüzyıl başlarında osmanlı devletinde yabancı devletlerin kültürel ve sosyal müesseseleri. Ankara: Atatürk Araştırma Merkezi Yayınları.

The Story of Robert College at Constantinople, Published by the Board of Trustees, 1918, s. 4. Columbia University, Rare Books and Manuscripts Library, New York.

Toprak, Z. (1993). "Robert Kolej” dünden bugüne. İstanbul Ansiklopedisi (C.6, s. 335-338). İstanbul.

Toprak, Z. (2003). Demokrat Parti, Lozan ve Robert Kolej. Toplumsal Tarih Dergisi. Sayı. $120,92-97$ 
Ulusoy, Ş. (2005). Robert Koleji ve yabancı okullara yönelik Atatürk Döneminde yapılan düzenlemeler. Yüksek Lisans Tezi. Yüzüncü Yıl Üniversitesi, Van.

Washburn, G. (1909). Fifty years in Istanbul and recollections of Robert College. Boston and New York: The University Press Cambridge. Türkçesi; Washburn, G. (2011). Istanbul'da 50 Yıl, (Robert Kolej Hatıraları). İstanbul.

Yazıcı, A. (2010). Türkiye'de azınlık, yabancı ve Türk özel okulları (1950-1960). Yüksek Lisans Tezi. İstanbul.

Yıldız, Ö. (2011). Anadolu'da Amerikan okulları. İstanbul. 


\section{Extended Summary}

Robert College started education with only four students at the hills of Bebek in İstanbul in 1863. It was the first missionary school established outside the United States, beyond the Atlantic. Many people doubted that it would be successful. However, best administration and the selection of the best teachers made the college and its graduates best among its peers. The number of College graduates increased rapidly and they contributed in many fields to the life and well being of the society in which they lived. In this article, firstly, information will be given on the College, its registered students and its graduates followed by the information on the education given at the College. Finally, Turkish graduates of the College are studied on the basis of various fields that they contributed to the society in which they were living.

\section{Purpose}

This study is conducted to unearth the conditions in which Robert College students educated and graduated: Particularly the nature and the quality of the education they received during their scholl years and classes they attended. It also conducted to find out the numbers and occupations of the graduates. These are used twards the ultimate purpose of the study which is to find out the contributions of the graduates to the society in which they were living and to find out how effective the education was at the College.

\section{Method}

Some archival documents from the Archives of Columbia University New York and Digital Archves of the Illinois University at USA are exploited. Statistical as well ad qualitative data in the documents are used by conventional historical methods.

\section{Results}

Results of the study is that, the college provided first class education which covered all the fields of science and language including mother tounge as well as some old languages such as Latin And Greek. As to the graduates, as the statistics show, only small amunt of them (5.4\%) were lucky to be graduated. Overwhelming amount of the studenst left the College before graduation. However, the education they received during their years at the College seems sufficient for them to be successful in real life, as they occupied high profile occupations and positions in the society in which they lived i.e. Ottoman and their 
own societies. It seems that, many graduates played crucial roles at the formation and modernization of the new Republican society.

\section{Discussion}

The education students received at the College, as we studied, based mainly on language, their mother tounge and foreign language, and covered a wide range of subjects from chemistry to mineroloji. This, certainly extended their horizon and opened up new doors to the life. They also gained new perspectives which helped them to know and cover the world as a whole. We however did not studied the classes students received and the books they read in detail which might be useful to understand the minds and worlds of them in detail. College graduates were in minority due to the conditions of their time. Most of the students left College before graduation. Still they occupied high positions in the society. As to the Turkish studets, we do not have coherent data to study them. We have only sporadic data that makes them to study individually, as we did. Turkish students benefited from the College at best during the Republican period when the non Muslim students left and Turkish society become a nation state.

\section{Conclusion}

We may conclude that the College has been successful thanks mainly to its education that was organized around the principle that education is best instrument to change people and thus the society. Its students equipped with the best knowledge and learned the best moral and religious values that made them ready for future. These qualities distinguished them among their peers and gave them knowledge and courage to start ahead in life and contribute to their society. Robert College, thus, become the best and the oldest educational institution established outside the United States and contributed to the modernization of the Ottoman and Turkish societies. 